DOI https://doi.org/10.18551/rjoas.2020-10.01

\title{
THE INFLUENCE OF THE STATE DEFENSE PROGRAM AND SOCIAL MEDIA ANALYSIS ON IDEOLOGICAL MENTAL DEFENSE WITH EDUCATION AS AN INTERVENING VARIABLE AT SIDOGIRI ISLAMIC BOARDING SCHOOL, PASURUAN REGENCY OF INDONESIA
}

\author{
Slamet M.S. ${ }^{*}$, Fanani Z., Moeljadi, Tjahjanulin \\ University of Brawijaya, Malang, East Java, Indonesia \\ *E-mail: jurnalpps13@gmail.com
}

\begin{abstract}
This study aims to analyze and examine the effect of state defense programs and social media on ideological mental Defense with education as an intervening variable at Sidogiri Islamic Boarding School, Pasuruan Regency. This research is a field research with quantitative methods. In this study, primary data were obtained from the results of respondents' answers or questionnaires given to the students at Sidogiri Islamic Boarding School, Pasuruan, East Java. Secondary data were obtained from various institutions which related to this research, such as the Ministry of Religion of the Republic of Indonesia, the Ministry of Religion of East Java Province, the Ministry of Religion of Pasuruan Regency and other Service Institutions. Data analysis used was path analysis. The results showed that education had a significant effect as an intervening variable in the relationship between the State Defense Program and the Mental Resistance of Islamic Ideology.
\end{abstract}

\section{KEY WORDS}

State defense, social media, mental defense, ideology, students.

Education is a process that includes three dimensions; the individual, society or national community of the individual and the entire content of reality, both material and spiritual, which plays a role in determining the nature, destiny, form of man and society. Education is more than just teaching, which can be said to be a process of knowledge transfer, value transformation, and personality formation with all the covered aspects (Nurkholis, 2013).

State Defense Education cannot be separated from the goals of national education, as stated in Law no. 20 of 2003 about the National Education System states that: "National education has the function of developing capabilities and shaping dignified national character and civilization in order to educate the nation's life, aimed at developing the potential of students to become human beings who believe and fear in God Almighty, have noble character, healthy, knowledgeable, capable, creative, independent, and become a democratic and responsible citizen (article 3 of Law No. 20 of 2003)".

Preliminary State Defense Education is intended to carry out efforts from state defense and security, that one form of people's participation in the defense of the State Defense program is by participating in the Preliminary State Defense Education (PPBN) which cannot be separated from the National Education System. With the implementation of State Defense Education in the school environment and outside the school environment, it will produce citizens who love the homeland, are willing to sacrifice for the nation and state, are confident in the supernatural powers of Pancasila and the 1945 Constitution and have an awareness of the rights and obligations as responsible citizens. The implementation of this Preliminary National Defense Education is inseparable from the goals to be achieved is to face the era of globalization that can threaten the existence and integrity of the Indonesian nation by obtaining State Defense Education, Indonesian people are expected to become quality humans, especially humans who are able to face challenges in the future that can guarantee the upholding of national identity and integrity (Subagyo, 2004).

Sidogiri Islamic boarding school is not affected by modernity; it is able to survive its traditionalism. Sidogiri Islamic Boarding School curriculum does not merge with the current 
demands of the era; it is able to maintain the characteristics of the boarding school and to actualize its existence amid the demands of society. Sidogiri Islamic boarding school which is located in the Sidogiri area, Pasuruan, East Java focuses its teaching on fostering morals, this is because it sees the condition of society which is experiencing more of mental and moral crises. In the midst of competition for educational institutions to create favorite, excellent and international standard schools and so on, Sidogiri Islamic Boarding School still maintains its stance, which is preserving the tradition of the teachings of the previous clerics. However, this does not mean that students are blind to technology. Science learning is still taught, such as developing interests and talents (Halimah, 2016)

As an institution that is engaged in religious and social education, the development of Islamic boarding schools should be encouraged, because the development of boarding school cannot be separated from the obstacles that must be faced. Currently, the world dynamically has shown rapid development and change, which of course, either directly or indirectly, can affect the world of boarding school.

The formulation of the problem in this study is how significant is the effect of education on the mental Defense of Islamic ideology in Sidogiri Islamic Boarding School, Pasuruan Regency?

\section{METHODS OF RESEARCH}

Research approach. The research to be carried out is a field research which is carried out by conducting a survey or going directly to the object of research.

Types of research. This research uses quantitative research, because the data obtained is in the form of numbers. Quantitative data is data obtained in the form of computable numbers (Missbahuddin, 2014). In this study, quantitative data were obtained directly from filling out the questionnaire as a research instrument.

Data source. The types of data used in this study include secondary and primary data. Primary data sources are data obtained or collected directly in the field by people conducting research or those concerned who need (Missbahuddin, 2014). In this study, primary data were obtained from the results of respondents' answers or questionnaires which given to Students at Sidogiri Islamic Boarding School, Pasuruan, East Java. Secondary data were obtained from various institutions related to this research, such as the Ministry of Religion of the Republic of Indonesia, the Ministry of Religion of East Java Province, the Ministry of Religion of Pasuruan Regency and other Service Institutions.

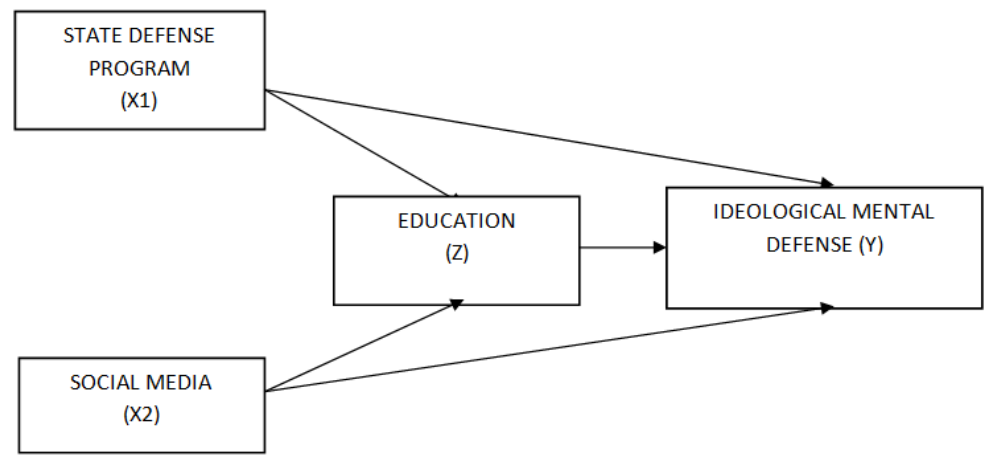

Figure 1 - Path Diagram of the Influence of State Defense and Social Media Programs on Ideological Mental Defense with Education as an Intervening Variable

Data analysis. To test the effect of the intervening variables, the path analysis method is used. According to Ghozali, path analysis is an extension of multiple linear regression analysis or path analysis is the use of regression analysis to estimate the causal relationship between variables (causal model) that has been predetermined based on theory (Ghozali, 2007). 


\section{RESULTS AND DISCUSSION}

Description of the characteristics of the respondents:

- The majority of respondents has a fairly high sense of love for the country and understands the importance of defending the country according to their respective capacities. This is evidenced by the active participation of respondents in participating in activities such as flag ceremonies and commemoration of Independence Day, as well as the willingness of respondents to accept the differences that exist in Indonesia;

- Respondents are still actively using social media as part of their daily activities. On average, respondents feel open to technological changes and are able to use them for positive activities such as learning, communicating, and entertainment. This is supported by the fact that the Sidogiri Islamic Boarding School does not prohibit its students from using the internet and social media, as long as its intended use is positive. Even the Sidogiri Islamic Boarding School supports the development of students to become technology literate through journalistic and ICT coaching;

- Respondents feel that the Sidogiri Islamic Boarding School has provided excellent service, so that its students get the best education. Besides, the respondents also thought that the education which carried out at the Sidogiri Islamic Boarding School had implemented a state defense and patriotism program that was in accordance with the capacity of the students;

- The majority of respondents understand very well what Pancasila is. Furthermore, respondents also considered that the application of the Pancasila ideology to their daily activities was a clear proof of love for the country and defending the country that could be carried out according to the respondent's capacity as students.

The Effect of State Defense Program on Ideological Mental Defense with Education as an Intervening Variable. The influence of the State Defense Program on Ideological Mental Defense is an indirect effect because it passes the Education variable as an intervening variable. The National Education Curriculum contains very little material on State Defense. The formal National Education Curriculum, starting from Kindergarten (TK) to Higher Education, contains very minimal material on State Defense, even though the formation of the nation's character starts early, when children are still sitting in Kindergarten (TK). If a child is formed a sense of nationalism, national insight, Pancasila values, a militant attitude of defending the country will grow (Suriata, 2019).

In fact, State Defense Learning is not a new thing. State Defense Learning at the tertiary level was previously given in Citizenship Education courses, Pancasila, and other general compulsory courses, with the aim of forming a strong national character for students who would later become graduated with knowledge, character and dignity. Now State Defense Learning in tertiary institutions must be given to students in the form of curricular, extra-curricular and co-curricular in broad terms as education that emphasizes strengthening national character. State Defense Learning can build traditions, work ethic, and lay down noble values as a foundation for intellectual development along with professionalism and vocationally.

The variety and combination of the implementation of State Defense Learning is very varied, including implementing learning through general compulsory subjects whose learning outcomes refer to the points of State Defense, service learning in the form of Real Work Lectures, State Defense training to trigger and spur national character; carry out interdisciplinary discussions; presenting and discussing with figures (historians, cultural observers, national leaders, etc.); or organizing sports and or the arts to stimulate sportsmanship and sensitivity.

State Defense Learning is based on deliberate and systematic principles. There is a special design made by universities to hold this State Defense Learning. For its implementation, lecturers are prepared from all disciplines in higher education and are monitored and evaluated regularly. To determine its success, the programs and activities 
carried out must be measured for changes in knowledge, attitudes, and in the long term changes in student behavior (practice / behavior).

The results of Rahmawati's (2017) research on the effectiveness of state defense education in increasing the nationalism attitude of Indonesian students abroad show that State Defense Education through the Citizenship Education subject is still not effective because it is constrained by aspects such as: Teaching competence does not meet the requirements for teaching defense the state because they do not have special teacher education; There is no learning module that contains specific State Defense Education teaching materials; Teaching and Learning Activities (KBM) for Citizenship Education are only delivered once a week; and the ineffectiveness of extracurricular activities that support state defense education.

The Influence of Social Media on Ideological Mental Defense with Education as an Intervening Variable. The influence of social media on ideological mental Defense is also an indirect effect because it passes the education variable as an intervening variable. The use of social media as a learning medium has supported a classic theory of social learning theory. This theory says that the social learning process focuses on how an individual learns by making other people the subject of his learning (Bandura, 2006).

In addition to learning about a simple behavior regarding a person's expertise, in social media it can also be found how an individual learns and begins to think about the consequences that will arise from the behavior carried out by his learning subject. Social media in its continuation not only teaches how a communication and information technology has an impact, but also teaches how a communication technology is absorbed and adopted (Bandura, 2006). The use of social media is now common in the distance education process (e-learning) where the teaching and learning process is no longer limited to classrooms, distance and time.

Social media has its own appeal for everyone, as well as teenagers. Based on the results of research which conducted by the Ministry of Communication and Information in Kalasi (2014), it is concluded that the use of social media is closely related to the daily lives of teenagers. In this study it was found that 98 percent of the adolescents surveyed knew about the internet and 79.5 percent of them were internet users. The attractiveness of the internet and social media then plays an important role in building one's communication skills. Teenagers today are very sensitive to changes that occur in social technology; they follow these developments and master it with the learning process using the trial and error method (Kalasi, 2014).

\section{CONCLUSION}

Education has a significant effect as an intervening variable in the relationship between the State Defense Program and the Mental Defense of Islamic Ideology at the Sidogiri Islamic Boarding School, Pasuruan Regency.

Education does not have a significant effect as an intervening variable in the relationship between Social Media and the Mental Defense of Islamic Ideology at Sidogiri Islamic Boarding School, Pasuruan Regency.

\section{SUGGESTIONS}

The curriculum that related to State Defense Education in schools has only been delivered through the subject of Citizenship Education, so there is a need for an improvement in the education curriculum in Islamic boarding schools that accommodates the State Defense Program so that students gain a deeper understanding of State Defense.

With the rapid development of information technology, especially social media, social media should be used as a medium for learning in the classroom to support the State Defense Program at Islamic boarding schools, for example assignments via blogs or videos uploaded to social media. 


\section{REFERENCES}

1. Bandura, A. 2006. Guide for Constructing Self-Efficacy Scales. Self-efficacy beliefs of adolescents, 5(1), 307-337.

2. Ghozali, Imam. 2011. Aplikasi Analisis Multivariate Dengan Program SPSS. Semarang: Badan Penerbit Universitas Diponegoro, hlm 105.

3. Kalasi, Rasmita. 2014. The impact of Social Networking on New age Teaching and Learning: An Overview. Journal of education \& social policy vol.1.Overview. Journal of education \& social policy vol.1.

4. Misbahuddin and lqbal Hasan. 2014. Analisis Data Penelitian Dengan Statistik. Edisi Kedua. Jakarta: Bumi Aksara, hlm 22.

5. Nurkholis. 2013. Pendidikan dalam Upaya Memajukan Teknologi. Jurnal kependidikan. Vol 1(1): 24-44.

6. Rahmawati, Ineu. 2017. Efektivitas Pendidikan Bela Negara Dalam Peningkatan Sikap Nasionalisme Siswa Indonesia Di Community Learning Center Sarawak Malaysia. Jurnal Program Studi Manajemen Pertahanan April 2017, Volume 3, Nomor 1.

7. Subagyo. 2004. Metode Penelitian dalam Teori and Praktek. Jakarta: Rineka Cipta.

8. Suriata, I Nengah. 2019. Aktualisasi Kesadaran Bela Negara Bagi Generasi Muda Dalam Meningkatkan Ketahanan Nasional. Public Inspiration: Jurnal Administrasi Publik, 4 (1) (2019), 47-56.

9. Undang-undang Republik Indonesia nomor 20 Tahun 2003 Tentang SISDIKNAS (Bandung: Citra Umbara. 2006), 72. 